\title{
Author Correction: Significant underestimation of radiative forcing by aerosol-cloud interactions derived from satellite-based methods
}

\author{
Hailing Jia (D), Xiaoyan Ma, Fangqun Yu(D) \& Johannes Quaas (D)
}

Correction to: Nature Communications https://doi.org/10.1038/s41467-021-23888-1, published online 15 June 2021.

The original version of this Article contained an error in the acknowledgments.

'This research has been supported by the National Key R\&D Program of China (grant nos. 2019YFA0606802 and 2016YFA0600404)' should have read 'This research has been supported by the National Key R\&D Program of China (grant no. 2019YFA0606802)'.

This has now been corrected in both the PDF and HTML versions of the Article.

Published online: 06 July 2021

\footnotetext{
(c) (i) Open Access This article is licensed under a Creative Commons Attribution 4.0 International License, which permits use, sharing, adaptation, distribution and reproduction in any medium or format, as long as you give appropriate credit to the original author(s) and the source, provide a link to the Creative Commons license, and indicate if changes were made. The images or other third party material in this article are included in the article's Creative Commons license, unless indicated otherwise in a credit line to the material. If material is not included in the article's Creative Commons license and your intended use is not permitted by statutory regulation or exceeds the permitted use, you will need to obtain permission directly from the copyright holder. To view a copy of this license, visit http://creativecommons.org/licenses/by/4.0/.
}

(c) The Author(s) 2021 